\title{
O poder e a autoridade dos autodesignados pajés na construção de uma expectativa de direito em comunidades quilombolas: Religiosidade e Territorialidade na Baixada Maranhense $^{1}$
}

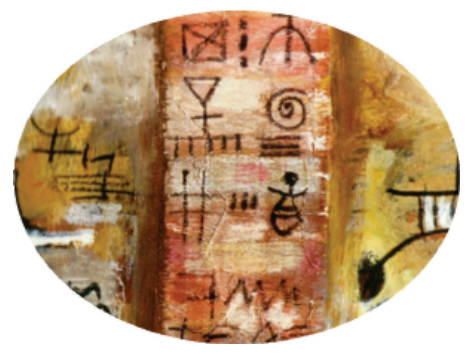

Patricia Portela

Cynthia Martins

\section{Resumo}

O artigo se propõe perscrutar a relação entre saberes e práticas referidos ao universo religioso e os processos de afirmação de territorialidades e identidades étnicas em uma área de ocupação antiga, precisamente, nos municípios de Alcântara e Penalva, localizados na região conhecida como Baixada Maranhense. Nessas situações tomadas para análise elementos simbólicos da ordem do sagrado estão investidos na "terra" ou "território", orientando a relação com os recursos naturais e as próprias relações sociais. Conforme buscaremos mostrar estes elementos simbólicos, investidos em práticas rituais e religiosas, organizam a vida social de maneira a reforçar a defesa de "territorialidades específicas” e de modos de vida próprios.

Nesse sentido, ao invés de tratar as práticas rituais e religiosas como elementos de coesão social capacitados a abrandar conflitos sociais, consoante a chave explicativa proposta pela sociologia da religião de viés funcionalista, nossa intenção é a de tratá-las como instâncias de politização e afirmação das identidades étnicas. 
Palavras-chave: Identidade e conflito social; território e domínio religioso.

\section{Abstract}

The article sets out to explore the relationship between knowledge and practices referred to the universe and the processes of religious assertion of territoriality and ethnic identities in an area of ancient occupation, precisely, in the municipalities of Alcantara and Penalva, located in the region known as the low lands. In these situations taken for analysis of the symbolic elements of the sacred order are invested in the "land" or "territory", guiding the relationship with natural resources and social relations. As we try to show these symbolic elements, invested in religious rituals and practices, organize social life in order to strengthen the defense of "territoriality specific" ways of life and themselves.

In this sense, instead of dealing with religious rituals and practices as elements of social cohesion able to slow down social conflicts, as the key explanatory sociology of religion proposed by the functionalist bias, our intention is to treat them as instances of politicization and assertion ethnic identities.

Keywords: Identity and social conflict; territory and the religious domain.

\section{Apresentação}

Considerando que o poder e a autoridade exercidos por funcionários religiosos a exemplo de pajés, pajoas, benzendores, benzedeiras, curadores, doutores do mato, consertadores de ossos, dentre outras categorias de autodefinição, transcendem o campo religioso stricto sensu, pretendemos tomar como foco de análise o domínio da produção e reprodução social de determinados saberes e práticas religiosas e culturais na intenção de investigar processos de construção de expectativas de direito em comunidades quilombolas.

Estes saberes e práticas nos permitem compreender a eficácia simbólica do campo religioso no que respeita ao que os agentes representam como "terra"

90 Somanlu, ano 11, n. 1, jan./jun. 2011 
e "território" mediados por uma politização das relações de força. Em desdobramento eles nos permitem deslindar processos de afirmação de territorialidades específicas, a exemplo das designadas terras de preto, terras de santo, terras da pobreza, que tornam o território indissociável das identidades étnicas constituídas.

Deste modo, o presente artigo busca apresentar os resultados parciais de pesquisas empíricas que vêm sendo realizadas em espaços referidos à produção e transmissão de práticas religiosas e culturais, notadamente nos designados terreiros, salões ou barracões na intenção de perscrutar o poder e a autoridade atualizados pelos mencionados funcionários religiosos na politização de conflitos que transcendem o domínio do próprio campo religioso.

As pesquisas de campo que temos realizado na região da Baixada Maranhense, nos municípios de Alcântara e Penalva² , estão referidas a situações agudas de conflito social resultado de ações governamentais que são direcionadas à implementação de Grandes Projetos e ao incremento do chamado agronegócio. Região esta que se caracteriza por ser uma área de colonização antiga dominada no passado colonial por fazendas e engenhos baseados na monocultura e no trabalho escravo.

Em nossas atividades de pesquisa de campo percebemos que há categorias especificas de autodefinição dos agentes religiosos tais como os pajés, benzendores e doutores do mato. Observamos ainda que estas categorias fazem alusão a um campo discursivo polissêmico posto que delineiam domínios de relações próprios cujos significados são relacionais, isto é, nem sempre a mesma categoria possui o mesmo significado ou está referida às mesmas práticas.

No presente artigo trataremos dos pajés e benzedores da região de Alcântara e dos doutores do mato da região de Penalva mostrando em que medida o papel social desses agentes se distingue dos demais agentes sociais referidos às situações de conflito enfocadas na medida em que suas práticas e representações possuem, como veremos, eficácia própria, são reconhecidas coletivamente e acionam critérios identidários de forma a orientar inclusive a manutenção dos territórios ameaçados. 
Nesse sentido, nosso desafio será o de buscar mostrar as interrelações e conexões entre domínios de relações sociais que são tradicionalmente pensados como domínios distintos, apartados e independentes senão contraditórios, quais sejam: a política e a religião. Desde a famosa asserção de K. Marx e F. Engels em O Manifesto do Partido Comunista (1848) que toma a religião como o ópio do povo a literatura sociológica clássica parece separar tais domínios. Em verdade, antes mesmo desta assertiva, filósofos inspirados por Kant já haviam estabelecido tal distinção a exemplo de Herder e de Feuerbach. M. Weber ao estudar os três tipos de dominação legítima demarca a passagem do Estado Dinástico para o Estado burocrático-racional. Para Weber esta última forma de Estado é caracterizada pela substituição da dominação tradicional e da dominação carismática pelo tipo racional de dominação. Tais tipos de dominação descrevem a passagem da Casa Real, fundada nos vínculos de sangue, para a emergência do Estado Moderno e a organização burocrática, que enfatiza a lei, a meritocracia e a competência. É como se o reconhecimento dos poderes e qualidades extraordinárias do chefe e as crenças nas regras e poderes antigos, tradicionais cedessem lugar à existência de normas formais legais e abstratas (WEBER, 2000, p. 139-161).

No âmbito da produção dos antropólogos, George Frazer (1979) inspirado pelo pensamento evolucionista realizou uma investigação comparativa da história do mito, da religião e de crenças tidas como exóticas de modo a concluir que a humanidade passava por estágios de evolução: o estágio mágico característico das sociedades classificadas como "primitivas" era seguido por um estágio religioso e na seqüência pelo estágio científico, próprio das sociedades tidas como modernas. $\mathrm{O}$ esquema explicativo deste autor endossa, ou antes, valida a instituição da distinção entre sociedade primitiva e sociedade moderna. Antes dele, L H Morgan já havia definido três estágios da evolução cultural (selvageria, barbárie e civilização) e se dedicado ao estudo sobre as diferenças formas de governo concluindo que todas elas obedecem a dois modelos. O primeiro em termos cronológicos foi chamado de "societas", sendo seguido pelo "civitas". Esta primeira forma de governo se caracteriza por estar baseada em pessoas e em relações puramente pessoais,

92 Somanlu, ano 11, n. 1, jan./jun. 2011 
com prevalência das relações de sangue. Já a modalidade designada civitas estaria, segundo o autor, baseada no território e na propriedade, sendo distinguível, segundo Morgan, pela emergência histórica do Estado (MORGAN, 2005, p.41-66).

Por essa via explicativa, a chamada antropologia vitoriana parece ter garantido às chamadas sociedades modernas tanto a racionalidade (atribuível apenas ao pensamento científico), quanto o território (demos para os gregos), princípio da ideia de democracia por oposição ao ethnos, às relações de sangue e ao parentesco. Em desdobramento a religião e magia também estariam consoante, a este modelo de análise, restritas às chamadas sociedades primitivas, sendo denotativas de estágios atrasados de desenvolvimento social e tecnológico. Estes princípios de divisão constitutivos do modelo foram vulgarizados e cristalizados pelo senso comum douto. Figuram como prénoções sempre que se trata de colocar em discussão temas ligados às chamadas sociedade tradicionais ou tribais.

Pode-se argumentar que para muitos destes autores trata-se de uma distinção da ordem da abstração, sem correspondência empírica estrita, isto é, a separação entre política e religião seria uma separação conceitual que permite compreender processos sociais específicos. Investidas por esta perspectiva é que nos dispomos a abordar a separação entre estes domínios como instâncias de análise que nos ajudam a compreender os processos de afirmação da identidade quilombola e de luta pela garantia do uso continuado do território e dos recursos ecológicos.

De outra parte, os conflitos sociais que recobrem as situações ora descritas não serão tomados como elemento de desintegração social, por si e em si, de forma a apresentar-se um quadro de posições e papéis polarizados entre agentes afetados pela implementação de grandes projetos nacionais ou pelo agronegócio e seus rivais. Mas buscaremos tratar o conflito social como instrumento de análise que dá inteligibilidade a determinadas relações, posições e papéis sociais que poderiam estar excluídos quando se trata de pensar sobre processos de afirmação de identidades étnicas a exemplo daqueles veiculados por funcionários religiosos. Nesse sentido, os conflitos sociais em jogo se 
prestam como instrumento de análise que nos auxilia a delinear um campo de relações de força que é, conforme supomos, indissociável do processo de afirmação da identidade quilombola.

De um certo ângulo, estamos nos dispondo a colocar em discussão o poder e a autoridade de funcionários religiosos no âmbito dos processos correntes de afirmação da identidade étnica. Trata-se de uma fala em produção, por assim dizer, posto que referida a situações e processos sociais em tudo dinâmicos. Para tanto, tomaremos como foco um conjunto de saberes e práticas ou saberes-fazer que orientam o discurso de funcionários religiosos e que legitimam a construção de uma expectativa de direito de uma variedade de grupos sociais em situações distintas de conflito. Tais funcionários dividem, compartilham ou distribuem a fala sobre direitos com outros agentes sociais. Agentes estes que podem estar referidos ao domínio da mobilização política, objetivados em movimentos sociais ou em entidades associativas; ou que são considerados como portadores da história de sua comunidade _ capazes de desenredar o contexto de acesso do grupo ao seu território _ ou, ainda, agentes cuja autoridade está assentada em formas particulares de uso dos recursos ecológicos de forma a apresentar um discurso próprio legitimado por práticas e saberes específicos adstritos a formas de organização social.

Podemos adiantar que neste campo de acontecimentos discursivos, alusivo às formulações de percepção de direito, não há relações de disputas formalmente instituídas, mas um sistema de diferenciação e de relações que autoriza, por exemplo, que o status de um indivíduo possa ser construído a partir do exercício de diferentes papéis sociais. Nesse sentido, não é incomum que em situações de conflito aqueles que passam a representar as expectativas de direito do grupo em fóruns externos seja uma autoridade religiosa no plano das relações intra e inter-comunitária ${ }^{3}$. Importa observar ainda os critérios de transmissão dos saberes, ou seja, quem é autorizado a aprender ou a representar sua própria coletividade. Há critérios de competência e saber intransitivos em contextos onde o que está é jogo são processos de afirmação identitária e a luta pelo território? Ou poderíamos nos perguntar como se afirmam ou se transmitem os diferentes tipos de autoridade que são acionados nesses

94 Somanlu, ano 11, n. 1, jan./jun. 2011 
processos de politização? Quem são aqueles que detêm a fala legítima para assegurar uma perspectiva de direito no âmbito de relações de conflito com o Estado brasileiro ou interesses privados? De onde parte o discurso sobre o direito? Ou, de outra parte, poderíamos nos perguntar de acordo com as inquietações de Nancy Frazer (2001) sobre quais são os tipos de luta que estão em jogo e que orientam os agentes sociais a se afirmarem como quilombos: seriam lutas econômicas com objetivo estrito de assegurar direitos territoriais? Ou seriam lutas identitárias direcionadas ao reconhecimento cultural? Ou, antes disso, poderíamos nos perguntar se é de fato possível estabelecer tal distinção entre o econômico e o reconhecimento cultural nas situações empíricas ora descritas. Estas dentre outras questões orientam nossas reflexões.

\section{A religiosidade na Baixada Maranhense como instância de politização e afirmação identitária}

Atualmente, a região da Baixada Maranhense, precisamente o município de Penalva é alvo de conflitos territoriais em função da concentração de terras e da criação de bubalinos por pretensos proprietários de terras que adquiriram as chamadas "terras da união" a preços abaixo do mercado. Os bubalinos destroem as plantações tradicionais, designadas roças, e levam ao cercamento dos campos naturais, que bem caracterizam a ecologia desta região. Os campos naturais são áreas inundadas pelas chuvas que durante a estação denominada inverno, servem para a pesca de famílias que aí vivem há muitas gerações. Além da pesca e do cultivo de certos gêneros alimentícios, as famílias da Baixada Maranhense realizam em determinados meses a coleta do coco babaçu. As atividades de coleta e beneficiamento do coco babaçu são realizadas predominantemente por mulheres, de acordo com divisão social do trabalho que caracteriza economia familiar. Entretanto, o extrativismo do coco babaçu não se reduz à uma atividade meramente econômica posto que através dele se organizou movimento político de caráter interestadual, extrapolando as fronteiras físicas desta região de forma a mobilizar mais de 300 mil mulheres 
distribuídas em diferentes estados do norte, nordeste e centro-oeste do Brasil. Atualmente o cercamento dos mencionados campos naturais é realizado através de cercas elétricas; cercas estas que impedem as famílias tanto de coletar coco babaçu, no verão, quanto de pescar na estação chuvosa.

Outro problema vivenciado pelas famílias que residem na Baixada Maranhese é a implementação de Grandes Projetos desenvolvidos pelo Estado brasileiro a exemplo da criação de uma base de lançamento de foguetes espaciais no município de Alcântara que implicou tanto na desapropriação de terras em mais da metade da área do município, quanto na opção pelo deslocamento compulsório de 312 famílias para unidades administrativas denominadas de "agrovilas", ocorrido em 1986-87, e um conjunto de medidas de caráter restritivo quanto ao uso dos recursos ecológicos, da organização social prevalecente, bem como das manifestações culturais que têm ameaçado as formas de existência coletiva dos diferentes grupos sociais ${ }^{4}$.

O desenvolvimento deste Projeto de governo em Alcântara levou às comunidades atingidas a fundamentarem seus direitos nos termos do art 68 do Ato das Disposições Constitucionais Transitórias (ADCT) da Constituição Federal Brasileira de forma que em 2004 o Estado brasileiro reconhece 85.000 hectares do município como pertencentes às autodesignadas comunidades remanescentes de quilombos ${ }^{5}$. O impasse resultado do conflito com o designado Centro de Lançamento de Alcântara (CLA) permanece posto até o presente uma vez que o Instituto Nacional de Colonização e Reforma Agrária (INCRA) ainda não emitiu o título das terras nos termos do decreto que regulamenta os procedimentos para a titulação das terras quilombolas no Brasil.

A situação de conflito permanece agravada por novas ameaças de deslocamentos para aquelas comunidades que estão situadas dentro da faixa de segurança definida pelos militares ainda na década de 1980. Inicialmente conduzido pelos militares da Aeronáutica, desde 1994 com a criação da Agência Espacial Brasileira (AEB), que o projeto está sendo executado por civis. A partir de então houve uma mudança nos propósitos iniciais do projeto que eram orientados por interesses de utilidade pública e passaram a ser conduzidos por interesses privados e estrangeiros. As ações recentes da Empresa Binacional

96 Somanlu, ano 11, n. 1, jan./jun. 2011 
Alcântara Cyclone Space (ACS) têm violado o direito das comunidades quilombolas de Alcântara interpondo interesses comerciais ao território quilombola, oficialmente reconhecido (PEREIRA JÚNIOR: 2009).

Há outras situações de violação dos direitos na região chamada de Baixada Maranhense como os problemas relacionados às derrubadas das palmeiras, ao envenenamento de "pindovas" e à expansão do rebanho bubalino. Nessa região, além das palmeiras de babaçu, os juçarais também vêm sendo derrubados para a implantação de pastagens, que estão sendo intensificadas na região. Trata-se de grandes propriedades, estruturadas para a atividade agropecuária- com bovinos e bubalinos- aonde a atividade extrativa vem sendo eliminada de maneira drástica através da derrubada indiscriminada da palmeiras de babaçu (cf. ALMEIDA et al, 2005).

Essa região concentra povoados provenientes da desagregação de grandes fazendas, nas quais as famílias passaram a viver e construir relações sociais centradas no uso comum das terras e sem que haja necessariamente vínculos sólidos com o poder público. As próprias atividades econômicas desenvolvidas por essas famílias, centradas na agricultura, criação de pequenos animais, caça e pesca, propiciou certa autonomia em relação a formas de vivenciar a religiosidade. As festas para os santos são predominantes e duram dias consecutivos, assim como assim como há referências a seres sobrenaturais que organizam o universo simbólico, tais como os currupiras, mãe-d'água e fites. Em Penalva, por exemplo, todos esses seres são designados de invisis, responsáveis pela proteção das matas, campos naturais, rios e enseadas.

Com as ameaças que essas famílias passaram a receber, principalmente em função da venda das terras, com a lei de terras de 1968, a dimensão protetora desses seres passou a ser acionada de maneira a garantir a territorialidade. São seres que sempre protegeram e puniram ao mesmo tempo e que, diante das ameaças externas, passam a ampliar seu poder de punição aos situados fora do universo cultural propriamente dito. Como nos colocou um dos nossos informantes em Penalva - esse pessoal tá ameaçando a gente e não sabe o que pode acontecer com eles, nos temos nossas proteções. 
Em muitas dessas regiões as famílias passaram a se organizar em torno de reivindicações de direitos principalmente com a atuação de movimentos sociais, a exemplo do Centro de Cultura Negra do Maranhão (CCN) Movimento dos Atingidos pela Base de Alcântara (MABE) e Movimento Interestadual das Quebradeiras de Coco Babaçu (MIQCB).

Desde que a Constituição Federal promulgada em 5 de outubro de 1988 reconheceu direitos territoriais às designadas comunidades remanescentes de quilombo uma multiplicidade de comunidades e entidades de representação política vêm acionando o dispositivo legal correspondente ao artigo 68 do ADCT como forma de assegurar o acesso aos direitos que lhes são correspondentes e de dirimir conflitos sociais: o Art. 68 do ADCT institui como direito constitucional a propriedade definitiva das terras das referidas comunidades nos seguintes termos: Aos remanescentes das comunidades de quilombos que estejam ocupando suas terras é reconhecida a propriedade definitiva, devendo o Estado emitir-lhes os titulos respectivos.

O conjunto das ações encaminhadas pelos agentes sociais no sentido de fazer valer este dispositivo constitucional podem ser consideradas como representativas de uma nova relação jurídica firmada entre o Estado e os designados "povos indígenas e tribais" através da Constituição de 1988, que se fundamenta no reconhecimento da diversidade cultural e étnica. Nesse sentido, as políticas de assimilação destes povos à sociedade brasileira, até então prevalecentes, passam a ser preteridas a favor do reconhecimento de uma nova modalidade de apropriação formal de terras baseada no direito à propriedade definitiva para grupos sociais a exemplo dos quilombolas ${ }^{6}$.

O reconhecimento deste direito não dispensa, contudo, a construção de uma percepção de direito própria que, fundamentada em critérios étnicos, transcende aos preceitos legais do direito agrário. Aliás, a percepção própria de direitos inclui a presença de seres protetores que lutam no plano sobrenatural para que a vida social e os consequentes saberes locais sejam mantidos. Um exemplo dessa situação refere-se à conhecida pedra de Itacolomi, em Alcântara, percebida como um lugar de moradia dos encantados ${ }^{7}$ e que estaria sumindo em função das desestruturações causadas pela implantação do designado CLA.

98 Somanlu, ano 11, n. 1, jan./jun. 2011 
Ou ainda, a atribuição aos fracassos dos lançamentos aos tambores que ecoam nas matas em defesa da manutenção dos territórios.

Apesar do referido dispositivo constitucional não poder ser compreendido senão como o resultado de pressões exercidas por movimentos sociais, notadamente aquelas efetuadas pelas mobilizações camponesas anteriores à promulgação da Carta Magna, em 5 de outubro de 1988, o Art. 68 do ADCT tem sido considerado como ponto de inflexão, seja em relação ao significado da categoria "quilombo", seja em razão da mobilização dos agentes sociais para fazer valer não apenas um direito constitucional, mas uma concepção de direito que incorpore o fator étnico como instância legítima de reconhecimento.

Enquanto categoria jurídica, que institui uma nova figura de direito, o significado de quilombo não pode ser dissociado do campo político e da prevalência de temas e problemas que o legitimam publicamente, alçando-o à condição de problema oficial.

Nas situações analisadas, os agentes sociais incorporam a categoria quilombo como autodefinição e elegem elementos próprios de sua cultura explicitando conteúdos que assumem caráter de comprovação da condição quilombola para "os de fora". Como nos colocou um dos nossos informantes sim, nós somos quilombo porque temos nossos guias protetores que vem do tempo antigo (...). Critérios religiosos e de ancianidade são constitutivos da identidade do grupo como quilombola e são indissociáveis da construção de uma percepção de direito.

Além do 68 do ADCT, os constituintes aprovaram em 1988, o artigo 215 direcionado para a garantia das "manifestações culturais" dos grupos “participantes do processo civilizatório nacional" (art. 215 \$1o da CF/1988), nos quais são indicados os designados "afro-descendentes, e o artigo 216 que trata do "patrimônio cultural brasileiro", determinando o tombamento de "todos os documentos e os sitios detentores de reminiscências históricas dos antigos quilombos" (art. $216 \$ 5^{\circ} \mathrm{da}$ CF/1988).

O conjunto destes dispositivos constitucionais fundamenta as ações de reconhecimento jurídico de uma multiplicidade de grupo sociais que se 
autoidentificam quilombolas e autorizam a afirmação de modos de ser e de viver específicos.

Em termos de uma possível reflexão e análise crítica sobre a diversidade dessas situações empíricas, a teoria antropológica nos ajuda a situar esses processos de reivindicação de direitos perante o Estado Brasileiro como processos concomitantes de construção identitária _ ou seja, ao acionarem o art. 68 do ADCT esses grupos estão afirmando uma determinada identidade: a identidade como comunidade remanescente de quilombo.

Nesse sentido, o presente artigo referenda Max Weber e suas contribuições teóricas aos estudos dos designados grupos étnicos. Weber contraria a concepção de grupo étnico fundamentada nas relações de sangue, destacando, em vez disso, o sentimento de comunhão étnica como fator potencial para a ação política ${ }^{8}$.

Nesse sentido Weber nos permite considerar os processos de afirmação das identidades étnicas como fenômenos políticos de modo a desautorizar as visões instrumentalistas que reduzem tais processos à defesa de interesses econômicos stricto sensu.

De outra parte, os autores que se dedicam ao estudo da etnicidade são levados a reconhecer que a relação com o Estado é diferente da relação com os vizinhos. Thomas Eriksen chama atenção que a etnicidade pode ser uma propriedade de uma formação social particular e um aspecto de interação. Isto significa considerar, segundo este autor, que a produção da etnicidade que envolve um estado nacional moderno é qualitativamente diferente da etnicidade acionada em uma vizinhança porque um Estado e um indivíduo são tipos diferentes de agentes (ERICKSEN, apud PORTELA, 2010). Esta distinção efetuada por Ericksen nos autoriza a pensar os processos de afirmação da identidade quilombola perante o Estado brasileiro e em termos de acesso a direitos instituídos por lei a partir de dimensões analíticas distintas: isto é, processos de afirmação da identidade quilombola podem ser observados tanto no plano das interações com grupos sociais vizinhos ou no plano das relações com Estado. Trata-se de dimensões de análise distintas de um mesmo processo e não de situações empíricas antitéticas.

100 Somanlu, ano 11, n. 1, jan./jun. 2011 
Fedrick Barth (1969) chama atenção que o problema dos grupos étnicos está na fronteira e não no conteúdo cultural - isto é, ele entende o processo de construção de identidades como um processo que se caracteriza pela relação que os atores sociais mantêm para fora enfatizando o contexto de interação em relação ao qual os diferentes atores acionam as identidades étnicas. Propõe em desdobramento que a característica crítica dos grupos étnico passe a ser a autoatribuição e a atribuição pelos outros com os quais se interage. ${ }^{9}$

A literatura antropológica referida aos estudos de etnicidade vale-se do conceito de estereótipos para a análise e reflexão de categorias identitárias como as acima mencionadas _ de autoatribuição e atribuídas por outrem. O'Dwyer ressalta a esse respeito que no caso das chamas comunidades negras rurais no Brasil certos estereótipos podem ser acionados no sentido comunicar certas diferenças culturais.

Assim, a análise de situações de afirmação da identidade como comunidade remanescente de quilombo nos permite considerar que o território, a identidade e a construção de uma perspectiva de direito caminham juntos, por assim dizer, como dimensões analíticas distintas de um mesmo processo (PORTELA, 2010).

Consideremos desse modo e através das colocações de F. Barth (1969), que as situações sociais analisadas podem nos permitir depreender que a concepção de ethnos se deslocou de uma acepção essencialista para outra que aceita o caráter situacional como elucidativa do seu significado.

Assim, ao invés de tratar as práticas rituais e religiosas como elementos de coesão social capacitados a abrandar conflitos sociais, consoante a chave explicativa proposta pela sociologia da religião de Durkheim, buscaremos tratálas como instâncias de politização e afirmação das identidades étnicas. Isto não implica, contudo, numa tomada de posição que em tudo reforça as teorias sociais do conflito. Ou seja, não se trata de acionar chaves explicativas como a do conflito ou a da "harmonia coerciva" (NADER, s/d), mas de ter em vista os significados atribuídos a práticas rituais e religiosas como estratégias de luta acionadas em situações agudas e continuadas de conflito. 
Godelier parece reforçar essa perspectiva em seus trabalhos mais recentes ao afirmar que nem na sociedade baruya, nem em qualquer lugar do mundo o parentesco serviu de fato como base e fundação de uma sociedade. Mais que isso, este autor afirma que nem as relações de parentesco, nem as relações de produção podem explicar o nascimento da sociedade baruya. Estabelece desse modo uma interlocução com as proposições de Levi-Strauss a respeito das relações de aliança e de Marx sobre as relações de produção, argumentando que aquilo que une certo número de grupos de parentesco em uma sociedade são suas relações políticas e religiosas (GODELIER, apud PORTELA, 2011).

Carlo Ginzburg ainda nos serve de inspiração, ao atentar para uma dimensão ainda pouco estudada a respeito da feitiçaria, considerando-a como uma arma de defesa e ataque nas lutas sociais (GINZBURG, 1989, p. 21). Podemos adiantar, a esse respeito, que no embate com o designado Centro de Lançamento de Alcântara os agentes sociais objetivados em movimentos e entidades de representação afirmam que não se eximem em recorrer a conhecimentos de natureza religiosa. Ressaltam que em dias de lançamento de foguetes pode ouvir-se em certas comunidades o som dos tambores. De outra parte, as histórias épicas relativas àqueles que invariavelmente escapavam a todas as tentativas de aprisionamento no período colonial corroboram com esta perspectiva de análise:_ através delas, os agentes são levados a caracterizar estes heróis do passado como feiticeiros ou mondogueiros, portadores de atributos tidos como mágicos.

Nesse sentido nos cabe perguntar quais são os agentes religiosos que integram o universo mítico e religioso de referência e quais são os saberes que entram em jogo quando se trata da gestão dos recursos ecológicos e que autorizam aos agentes investirem na construção de uma expectativa de direito. Para tanto, temos em vista tomar o conceito de "saber prático", inspirado em Michel Foucault ${ }^{10}$. Em sua proposição, o conceito de saber antes de ser tomado em termos de conhecimento é entendido através de um conjunto de elementos que orienta a prática dos agentes nos diferentes lugares institucionais ou domínios de interação social onde estes obtêm seu discurso. O saber implica

102 Somanlu, ano 11, n. 1, jan./jun. 2011 
assim em prática por oposição a conhecimento formal e metódico (FOUCAULT apud PORTELA, 2011). Em uma perspectiva aproximada F. Barth (1995) trata destes saberes práticos como modos de conhecimento que bem caracterizam as variações culturais e os elementos da fronteira étnica. Variações estas que nos ajudam a entender, conforme supomos, os processos de afirmação identitária em jogo.

\section{Os pajés e curandeiros em Alcântara ${ }^{11}$}

Como já mencionamos, em 1980 terras do município de Alcântara foram objeto de ação de desapropriação sancionadas pelos citados decretoslei com o propósito de criação de uma base de lançamento de foguetes espaciais. As ações de desapropriação de terras atingiram, no entanto, quase duas centenas e meia de povoados que viviam autonomamente e sem ingerências significativas do poder público já que não existiam quaisquer serviços de infraestrutura, como energia elétrica, saneamento ou rodovias que desse acesso aos povoados localizados no interior do município. Nem mesmo a cidade de Alcântara parecia contar com o investimento público que fornecesse aos seus moradores alguma expectativa de romper com a imagem de penúria cristalizada por historiadores e literatos a seu respeito: os primeiros precisam as clivagens históricas que teriam levado a aristocracia alcantarense à falência ao longo dos séculos XVIII e XIX, endossando como expressão erudita a decadência da lavoura, enquanto os literatos descrevem em detalhes os símbolos da decadência cristalizando esta forma de representar Alcântara e os alcantarenses.

Estes autores levam seus leitores a deduzir que Alcântara tivera em passado remoto um período de apogeu econômico suficientemente expressivo para formar uma classe dirigente culta e abastada. Tal dedução deriva em verdade de seu oposto especialmente na fala de poetas como Ferreira Gullar que em seu Poema Sujo (1975) lembra com nostalgia das ruínas de Alcântara: “... senão entre as ruinas a persistente certeza de que naquele chão onde agora crescem carrapichos eles [os habitantes] efetivamente dançaram (e quase se ouvem vozes e gargalhadas que se acendem e se apagam nas dobras da brisa)" (GULLAR, 1975, p. 57-58). 
O poema de Gullar faz referência a certa singularidade observada em Alcântara no tocante ao processo de desestruturação das fazendas e engenhos montados em fins do século XVII e decorrer do século XX. No interior do município, não se encontram no presente exemplares das casas-grandes, do passado escravocrata, a exemplo do que pode ser visto em outras regiões do país. O historiador Jerônimo de Viveiros considera que a decadência foi de tal ordem que todos os tipos de bens dos proprietários foram levados com suas mudanças para São Luís; desde objetos, como porcelanas e pratarias, até as telhas e as madeiras de lei das casas. A classe dominante parece assim ter abandonado, com a falência de seus empreendimentos, as fazendas, os engenhos e a própria cidade.

De outra parte, os cerca de duzentos e cinquenta povoados do município desenvolveram ao longo do tempo vínculos sociais referidos a relações de troca e auxílio mútuo que produziu certa interdependência entre estes. Não se trata de uma modalidade de relação de troca restrita ao plano econômico, mas é possível observá-la naqueles domínios referidos à política, à religião, às práticas de cura, aos rituais fúnebres, ao sistema de parentesco, dentre outros. Este sistema de interdependência não traduz, contudo, uma homogeneidade no estilo de vida: existem certas diferenças e peculiaridades que denotam a vigência de distintas comunidades de sentimentos (PORTELA, 2011, p. 30).

A situação de conflito instituída pelas ações do governo em Alcântara propiciou, no entanto, que as especificidades destas comunidades passassem a ser socialmente visíveis a exemplo dos diferentes contextos de acesso à terra e das expectativas de direito das diferentes comunidades. Situações referidas a casos de doação, aquisição, herança, com ou sem formal de partilha, concessão, ocupação ou apossamento são expressos através de diferentes nomenclaturas relativas aos domínios territoriais, sugerindo diferentes formas de classificação dos agentes sobre sua base territorial, tais como: terra da pobreza; terras de herança, terras de preto e terras de caboclo, terras de santo, terras de santa e terras de santíssima (ALMEIDA, 2006, p. 37).

Esta visibilidade social se atualiza não apenas externamente, face às instâncias de poder, mas torna-se perceptível para os próprios agentes que passam,

104 Somanlu, ano 11, n. 1, jan./jun. 2011 
a partir do conflito, a ter acesso aos meios de transmissão da terra referidos a outros povoados vizinhos. As muitas reuniões, seminários, audiências públicas, dentre outras modalidades de encontros organizados pelas lideranças políticas e sindicais proporcionam não apenas a muitos conhecer povoados vizinhos, como também propicia aos agentes ter acesso às narrativas daqueles tidos como portadores da história de cada lugar. Este conflito parece-nos, assim, ter propiciado aos agentes uma outra forma de percepção para as diferenças já legitimadas pelo sistema de relações sociais interpovoados, tanto quanto contribuiu para a fixação de fronteiras sociais de contornos mais espessos do que aquelas perceptíveis no plano das relações cotidianas. Funciona, pois, como instrumento privilegiado de observação e análise dos atos, práticas e relações sociais travadas pelos agentes sociais, notadamente no domínio político das relações, a fim de fazer valer as diferentes autodefinições que se tem em jogo em referência ao designado território étnico de Alcântara, isto é, a fim de instituir sujeitos e grupos sociais distintos entre si; de forma a sugerir que o território enfocado serve de referência para diferentes identidades sociais. Por essa razão considerar a vigência de um território étnico não significa considerar a prevalência de um território homogeneamente construído. Mas devemos considerar a vigência de diferentes territorialidades em referência ao que vem sendo apresentado como território étnico de Alcântara. (PORTELA, 2011, p. 53).

As mobilizações políticas que decorrem da luta pelos direitos nos permitem, assim, apreender um conjunto de relações de força que desenham um campo constituído por mediadores políticos e integrado por lideranças sindicais e aquelas ligadas aos pleitos quilombolas. A fala relativa aos direitos atualizada pelos delegados políticos e sindicais, no entanto, não prescinde de todo um conjunto de saberes, de práticas e de saber-fazer: os saberes portados por aqueles que são reconhecidos como portadores da história das diferentes coletividades; os saberes veiculados pelos chamados velhos seja sobre a história de acesso à terra, seja sobre o uso específico dos recursos ecológicos; ou ainda os saberes veiculados por pajés e benzedores da região.

Mas para se ter acesso ao universo religioso e aos significados simbólicos atribuídos a narrativas e práticas os pesquisadores precisam lidar com certos 
obstáculos. Não são tão fáceis as condições de pesquisa em Alcântara em razão da situação de conflito social agudo. A extensão de tempo decorrido desde os atos de desapropriação de terras corrobora para o clima de tensão, tanto quanto as ações continuadas de ameaça de deslocamentos compulsórios, já vividos em meados da década de 1980. O clima de tensão é permanente e reforçado por uma quantidade expressiva de estudos e levantamentos com fins cadastrais realizados por agentes do Estado.

Além disso, pela própria diversidade cultural mencionada acima não se pode buscar apresentar um quadro que homogeneíze a dispersão de práticas e representações. Por essa razão, os dados aqui apresentados antes de possuírem uma conotação geral, representativa de toda a área oficialmente reconhecida como comunidade remanescente de quilombo, são alusivos a certa região do município.

Em verdade, estes dados foram coletados nas comunidades que integram a designada terra da pobreza, uma das territorialidades específicas, dentre outras, que foram afetadas com a implantação do chamado CLA. Localizadas a noroeste do município de Alcântara, estas comunidades estão referidas ao contexto de desintegração de um antigo engenho de propriedade de Teófio José de Barros. Este, segundo os relatos, doou formalmente as terras às famílias nelas residentes há tempos "imemoriais". Trata-se de uma situação formal de doação que está registrada em documentos cartoriais. Documentos estes que estão guardados por moradores destas terras sendo apresentados como garantia de comprovação de seus direitos territoriais sempre que alguma autoridade ou estrangeiro curioso os indaga a respeito dos meios que lhes facultaram o acesso às terras.

Entrevistas, conversas informais e observações diretas são constitutivas do nosso material de pesquisa. Entrevistas e conversas informais foram realizadas com seu Domingos Ribeiro de Canelatiua, dona Maria de Gogó, como é conhecida, que reside no povoado de Bom Viver e sua irmã, dona Margarida então residente no povoado do Retiro. Além deles, também travamos conversas casuais com outros anônimos que tem fama de feiticiros na região, muito embora jamais assim se qualifiquem. Observações diretas foram realizadas durante o festejo de Nossa Senhora da Conceição, padroeira de Canelatiua, e no âmbito da vida cotidiana de trabalhadores rurais, pescadores, marinheiros experientes, carpinteiros navais, comerciantes ativos, dentre outras manifestações identitárias.

106 Somanlu, ano 11, n. 1, jan./jun. 2011 
No entanto, nosso principal informante foi seu Domingos, como é conhecido. Com ele realizamos longas entrevistas e tivemos um contato mais próximo resultado de longas estagias que passamos na casa vizinha, ao lado da sua. O peso de sua visão estará presente na descrição deste universo religioso e bem pode ser entendido como a adoção da perspectiva de um benzedor a respeito deste universo.

Para um morador da cidade de Alcântara, no entanto, seu Domingos é considerado uma espécie de doutor, um pajé ou um conselheiro em assuntos espirituais. Pelo que pudemos reunir de informações, sua reputação foi construída como um benzedor por oposição à figura do pajé. Certo número de distinções é por ele estabelecido entre suas atribuições, dons e habilidades que o distancia dos pajés de sua região. Além de ser reconhecido como benzedor, seu Domingos dispõe de saberes práticos relativos a certo conhecimento que possui no trato de ossos, articulações, ligamentos e tendões do corpo humano que o habilita a ser visto como um doutor local. Ele dispõe de critérios de competência e saber específicos para praticar o ofício conhecido como consertar ossos ou por ele designado como endireitar junta; através deste ofício ele é capaz de estabelecer uma rede de relações bastante vasta, que ultrapassa as fronteiras de sua comunidade.

Além disso, certos vínculos de amizade, parentesco e vizinhança lhe facultam o acesso ao domínio das festas religiosas; através destes laços ele é chamado a exercer atividades como festeiro ou encarregado de festas. Um tipo de saber também daí se desprende que lhe confere notoriedade e reconhecimento específico de seu valor. Seu Domingos ainda se coloca neste meio social como reputado padrinho congregando uma rede de afilhados, compadres e comadres que the permite estabelecer vínculos de reciprocidade com uma vasta gama de parentes de modo a insinuar que os tipos de laço que ele é capaz de criar transbordam as fronteiras da comunidade de parentes que ele representa.

A primeira distinção que se estabelece entre o ofício de consertar ossos e suas habilidades de benzedor diz respeito ao fato do primeiro ser adquirido, em comparação ao segundo que é tido como atribuído por nascimento. O ofício de consertar ossos requer experimentação, possui objetivo aplicado e é localizado, 
ou seja se exerce com referência a determinado domínio de relações sociais. Nesse sentido, o consertador de ossos faz parte de um domínio de interação integrado por todos aqueles habilitados à cura de doenças seja física seja espiritual: benzedores, padres, médicos ou pajés detêm tanto quanto o consertador de ossos poderes de intervenção sobre os destinos individuais.

Trata-se, contudo, de uma modalidade de saber em tudo distinta dos conhecimentos médicos, stricto sensu, isto é para se tornar um consertador de ossos não há como contar com um corpo de conhecimentos sistemático ou normas pedagógicas e condições legais que asseguram o monopólio do exercício deste ofício. Em verdade trata-se de um aprendizado adquiro pela prática, que se aprende fazendo - conforme explica seu Domingos. Adquire por essa via critérios de competência e saber específicos que lhe autoriza a identificar e a tratar de problemas designados por quebrado, tirado, desconjuntado, torcido, nervo e carne-aberta.

A ausência de condições legais para praticar este saber não implica em ausência de controle e sanções. A própria disputa por uma clientela de acidentados funciona nesses termos. Além disto, seria ainda possível discernir, dos relatos deste senhor, a importância de outros atributos, nem sempre confessos, embora permanentemente latentes para alguns. Trata-se de atributos referidos ao domínio dos saberes religiosos, em sentido estrito, que nos permite não apenas perceber uma hierarquia referida aos consertadores de ossos da região, quanto nos leva a relativizar a propensão em estabelecer uma rígida separação entre o domínio das enfermidades de foro espiritual daquele referido às doenças do corpo humano.

Nesse sentido, sob a ótica de seu Domingos, dons e visões religiosas fazem a diferença no exercício das atividades praticadas por um consertador de ossos. Eles distinguem as habilidades destes no trato dos ossos e instituem por esse viés uma hierarquia de autoridades referidas ao domínio que poderíamos designar como paramédico.

A literatura antropológica pertinente ao tema da cura de doenças, ou ao se convencionou chamar de "medicina primitiva", está coalhada de exemplos que evidenciam as conexões entre o domínio referido à cura de doenças e o domínio

108 Somanlu, ano 11, n. 1, jan./jun. 2011 
da religião. Em seu estudo etnográfico sobre a medicina Lunda, Victor Turner (2005, p. 379-447) assinala a importância de se deslocar o foco das atenções dos atos terapêuticos para as ideias que lhes são subjacentes. Busca, nesse sentido, mostrar que as ideias Lunda sobre o tratamento de doenças é perpassada por domínios mais amplos de crença e ação.

Em nossas pesquisas de campo cedo percebemos que não é nada fácil penetrar no universo das crenças religiosas. Nas entrevistas realizadas as falas referidas à expectativa de direito do grupo face ao conflito ou sobre os aspectos relacionados à organização social, econômica ou cultural parecem ser mais diretas e fluentes do que aquelas referidas a certas crenças e práticas. Logo compreendemos que há coisas sobre as quais não se fala, especialmente a forasteiros.

Assim, de nossa participação na Festa de Nossa Senhora da Conceição só tivemos acesso à versão oficial dos agentes: seja pela observação direta, seja pelas conversas informais e posteriores entrevistas, os agentes se dispunham a narrar a versão católica da festa ou a explicar sua logística. A despeito disto, pudemos perceber crenças e práticas relacionadas ao universo de pajés, feiticeiros e benzedores.

Inadvertidamente, soubemos que a limpeza da capela, que receberia a visita do padre da paróquia de Alcântara, era instruída por um benæęodor da região; assim como ouvimos comentários feitos sobre uma mulher que, por influência de maus espiritos, teria desacatado sua mãe durante os festejos - eventos extraordinários como as festas de santo parecem ser percebidos como palco privilegiado para atos, desavisados com este, que sugerem a atualização de certas crenças religiosas.

Pareceu-nos que, do ponto de vista dos fiéis, são tênues os limites que separam a religião ortodoxa destas outras crenças e práticas, conforme sugeriu Ginzburg ao tratar da repressão à feitiçaria pela Inquisição mondenense (GINZBURG, 1989, p. 33); trata-se de uma espécie de cadinho de crenças religiosas, conforme sugere este autor, que nos pareceu importante investigar.

Há, no entanto, uma distinção a ser estabelecida entre o silêncio mantido a forasteiros e os segredos mantidos entre àqueles (acho que não tem crase) que se tem como iguais - nesse domínio, do ponto de vista de um pajé ou de um benzedor certos segredos podem ser lidos como gerenciamento de um tipo de conhecimento que confere poder e autoridade àqueles que dele são portadores; à semelhança 
dos sacerdotes de culto de mistérios da Nova Guiné, observados por Barth (2000: 144) ou dos consertadores de ossos, benzedores e pajés da terra da pobreza.

Para além do saber específico no trato de ossos, o Sr. Domingos também é conhecido como benzedor. Outro domínio de saber daí se desprende que o permite tratar de problemas espirituais e físicos: encostos, quebrantos, mausolhados, flechas, ou tirar sangue por palavras, cubreiro, fogo selvagem, bucho de criança, dor de cabeça e complicações no parto são por ele identificados e tratados. Para tanto, faz uso de palavras mágicas, rezas e dos designados "remédios" 12 que incluem um conjunto amplo de diferentes tipos de banhos, pós, chás e pomadas a base de ervas medicinais. Todos estes tipos de problemas são percebidos como decorrentes de males físicos e espirituais ao mesmo tempo. Mas quebrantos, maus-olhados e flechas pertencem ao plano espiritual stricto sensu ainda que manifestem uma expressão física no corpo através de febres, cansaços ou moleza no corpo. Enquanto os demais males podem ou não ter como causa questões de ordem espiritual, que somente podem ser identificadas por aquele que detém critérios de discernimento específicos, como benzedores e pajés ${ }^{13}$. Além destes, o designado encosto adstrito ao plano espiritual não apresenta manifestações no corpo físico sendo perceptível através de atos indevidos praticados por alguém que dele fora alvo. Cada um destes males possui uma natureza distintiva, com causas específicas, variações na forma como se manifestam ou como podem ser identificadas. O benzedor pode fazer uso de suas mãos para perceber em que parte do corpo a designada flecha se alojou, pode ver encostos, pode ouvir vozes que lhe enviam mensagens, orientandoo em suas ações, pode sentir através de arrepios se o enfermo foi alvo de quebranto ou mau-olhado, assim como pode deduzir o malfeito, seja através de atos indevidos praticados pelo enfermo, seja através de acontecimentos que se impõem na vida de uma pessoa sem que haja uma causa aparente, conforme o Sr. Domingos indica abaixo:

Domingos: pois é isso; olha, porque eu tinha três bois, eu fui jurado que eu pelo menos não podia ter três bois e aí um já morreu, eu perdi um boi um dia desses, no dia três desse mês eu perdi um boi. Eu só tenho dois agora.

110 Somanlu, ano 11, n. 1, jan./jun. 2011 
Patrícia: mas o senhor foi jurado por quem? O senhor não sabe?

Domingos: eu não sei.

Patrícia: o senhor não sabe? E como o senhor sabe que foi jurado?

Domingos: eu sei que fui jurado porque os bois eram só de uma qualidade, ele era igual aos outros. E eu tinha comprado já dois bois e o outro era para comprar e eu não comprava. E o certo é que morreu um

(RIBEIRO, Entrevista, 14.7.2004).

Além disso, percebidos como uma espécie de dom dado pelo nascimento os atributos de um benzedor os autorizam a sonhar com os males a ele dirigidos, com rezas referidas a males específicos ou ainda a antecipar acontecimentos.

O mau-olhado e o quebranto são aproximados pelo tipo de motivação que induz alguém a praticar o malefício: a inveja motiva o ato. Mas guardam certa distinção com relação ao tipo de dano causado, ao modo como se manifestam no corpo físico e pela forma de transmissão. O primeiro é efetuado por pensamento e o segundo agrega pensamentos a atos, isto é, quem o pratica inveja, deseja o mal e faz algo para que o mal desejado tenha efeito. Dentre estes atos, os chamados preparos são tidos como mais eficazes e costumeiros. Trata-se de transmitir o malfeito por meio de alimentos que, ofertados, fazem de vítimas aqueles que os aceitam.

As designadas flechas, por sua vez, diferenciam-se dos males anteriores na medida em que estes são provocados ou por pessoas com quem o enfermo em questão interage, ou por espíritos do plano transcendental; já a flecha é resultado da ação de determinadas entidades que a despeito de também estarem referidas ao plano transcendental parecem transitar pelo mundo dos homens dispondo de uma posição hierárquica distinta: trata-se de seres encantados que circulam pelas matas, poços, rios e igarapés.

Domingos: Eu só sei se tem flecha, na cabeça ou no pé, se eu botar a mão e fizer uma reza eu sei se é uma flecha ou não é. Por que ela pula, ela passa em cima do meu dedo e eu sei que ela está lá. 
Patrícia: e como é a flecha?

Domingos: é um chucho, uma lança.

Delina: a Mãe D’água, né?

Domingos: a mãe D’água do poço, Vovó, Puxa-Vovó. Currupira aí já é diferente.

Patrícia: ah tá, mas aí não é a mando de ninguém, é a Mãe D’água que faz?

Domingos e Delina: é, é a Mãe D'água.

(RIBEIRO e RIBEIRO; Entrevista: 4.7.2004).

Espíritos de mortos, distinguíveis entre espírito de luz e encosto (espírito mal), encantados, distinguíveis entre entidades que circulam por matas, poços, rios e igarapés a exemplo da Mãe D'água e outros, que habitam a Pedra de Itacolomi, e são incorporados pelos pajés durante as designadas sessões de cura, ocorridas nos terreiros ou barracões em dias de festa de tambor de mina, integram o universo de seres sobrenaturais. Seres estes que asseguram a proteção da coletividade de parentes, amigos e vizinhos relativa às comunidades quilombolas que atingidas pela designada Base de foguetes lutam pelos seus direitos territoriais assegurados por lei.

Dentre as diferentes modalidades de males espirituais, o Sr. Domingos apenas não trata do feitiço que, em sua região, fica a cargo dos pajés. Benzedores e pajés disputam, de todo modo, a mesma clientela já que os pajés dispõem de competência para tratar de todas estas enfermidades. Ambos são percebidos como atores cujas práticas incidem sobre o conjunto de uma dada sociedade na medida em que poderes de intervenção lhes são atribuídos: poderes de cura espiritual e/ou física já que como enfermidades são vistas como indissociáveis; poderes políticos na medida em que são percebidos como chefes de suas coletividades; poderes de liderança que se colocam para além do domínio de suas comunidades; poderes de estabelecer trocas de serviços com uma vasta rede de agentes a exemplo dos vínculos de compadrio já que muitos anseiam pela proteção que podem vir a oferecer.

112 Somanlu, ano 11, n. 1, jan./jun. 2011 
O poder dos pajés é reconhecido e legitimado por meio do temor que suscitam como expresso pelo codinome de onça a eles atribuídos. Potencialmente, todo pajé é também feiticeiro já que o poder de praticar um benefício é percebido como homólogo ao poder de impetrar malefício a alguém. Isto é, ambos, pajés e feiticeiros, são vistos como detentores da mesma capacidade de intervir no plano espiritual. A distinção entre um e outro compete à escolha individual entre praticar o bem ou o mal. Enquanto categoria social, o pajé figura como categoria de auto-atribuição. Opõe-se nesse sentido à categoria feiticeiro, sempre atribuída por outro. Ninguém diz-se feiticeiro ou apresenta-se como tal. Mas no âmbito de um povoado ou em referência à rede de relações que um indivíduo é capaz de dispor os feiticeiros são passíveis de identificação, isto é, parentes, vizinhos e amigos dispõem de critérios específicos de discernimento que indicam aqueles que praticam feitiçaria, seja através da reputação como feiticeiro, seja através da posse de certos objetos, como as chamadas pedras de trovão, usadas em atos mágicos.

As habilidades de cada qual, pajés e benzedores, para tratar destes males são, no entanto, distinguíveis e constituem uma instância de diferenciação a partir da qual se evidenciam oposições. Pela oposição o Sr. Domingos é levado a afirmar sua identidade de benzendor e a ressaltar as fragilidades de um pajé: em sua visão, os poderes deste são redutíveis ao ato da cura. Além disto, o pajé é tido como suscetível a vaidades de forma que é levado a menosprezar certos princípios que orientam as ações dos agentes em referência a este universo social, a exemplo da desconfiança. Como princípio de ação a desconfiança se coloca como condição determinante para proteger os agentes de toda a sorte de malefícios potencialmente perpetrados.

Se os atributos requisitados ao ofício de endireitar junta é atribuído a certo saber transmitido por alguém que o possui, as habilidades específicas de um benzedor ou de um pajé são percebidas como tipo de dom dado pelo nascimento. Neste domínio de ação não há como transmitir saber em forma de ensinamentos - se não se nascer com este dom não há como aprender a se tornar um benzedor ou pajé. A transmissão nesse domínio é percebida como hereditária, passada de pai para filho. 
Dona Maria de Gogó, pajoa do Bom Viver, por exemplo, herdara o dom de cura de seu pai, tanto quanto os sete irmãos que possui ${ }^{14}$. Trata-se de uma família de curadores. Sempre há, no entanto, a possibilidade de alguns optarem por não exercê-lo a exemplo da decisão de uma irmã de dona Maria de Gogó, dona Margarida. Aos que escolhem não praticar as atribuições de dom é preciso recorrer aos remédios prescritos por um pajé. Mas, há também sempre a possibilidade deles não surtirem efeito como ocorreu com dona Maria ${ }^{15}$.

Maria: porque se a minha sorte é essa então eu tenho que cumprir até quando Deus quiser, não é? Não me faz mal!

Patrícia: e a senhora acha que a senhora herdou isso de alguém da sua família?

Maria: eu acho que eu herdei porque meu pai era e diz que a mãe dele mandou fazer remédio para ele e ele teve sete filhos mais mamãe, todos os sete tinha essa mania.

Patrícia: ah, então todos os seus irmãos tinham também?

Maria: henheim, só quem só bateu uma vez foi Madá [Dona Margarida], que mora no Retiro. Mas foi feito remédio para ela. E para mim não, pra mim não teve remédio. Até meu irmão [Dario, pajé conhecido], foi fazer remédio para mim, aonde! Foi quase um mês de doença pra ele. Aí ele largou de mão. Ficamos os dois latindo.

(MARIA DE GOGÓ; Entrevista: 4.7.2004).

(grifos nossos)

Ao que compete ao Sr. Domingos, notadamente, que congrega estas duas modalidades de saber (adquirida e atribuída) parece que certos atributos se entrecruzam: para tratar do chamado quebrado ou carne-aberta ele não dispensa rezas e palavras mágicas.

De outra parte, no plano das interações cotidianas, por exemplo, o exercício de suas atividades como consertador de ossos suscita invejas o que torna os rituais de defesa indispensáveis e sempre mais consistentes. Os rituais de defesa são, no entanto, necessários a todos já que todos são passíveis de inveja.

Nesse sentido, é que aquele que tem ciência do poder dos funcionários religiosos, a exemplo de um benzedor, é levado a discernir as intervenções

114 Somanlu, ano 11, n. 1, jan./jun. 2011 
destes nos mais variados planos de atividade social ou a conceber as relações de força entre aqueles que dispõem de poder temporal de forma algo invertida. Isto é as relações sociais mantidas entre os funcionários religiosos e aqueles que são vistos como detentores de algum tipo de poder (seja político, econômico ou intelectual) são percebidas através do vínculo de subordinação destes em relação aos primeiros. E isto na medida em que médicos, prefeitos, governadores e até mesmo presidentes da República não só não dispensam os serviços destes funcionários religiosos, como em verdade dependem destes serviços seja para a conquista seja para a manutenção de certo status social, conforme explica seu Domingos:

Domingos: Por que olha dona Patrícia, hoje não tem um médico, não tem um governador, um presidente, que não seja coisa.

Patrícia: coisa o quê?

Domingos: não seja médium, não seja [?]. A senhora acha que a senhora anda só com seu saber? Que a senhora sabe ler muito bem, vem de lá fazer essas pesquisas todinha nesse mundo todo. A senhora acha que eu acho que a senhora só tem um saber na cabeça? A senhora não tem nenhum saber com a senhora pra se defender? Não, eu não acredito! Que a senhora só com seu saber de a, b, c, d desses livros, de escrever e ler, a senhora sai nesse mundo de meu Deus todinho fazendo essas pesquisas. Porque há amigo e há inimigo! Tenho uns que conversam porque sabem as conversas pra lhe atrair.

Patrícia: mas como assim?

Domingos: aah!

Patrícia: mas então o quê que é ser médium?

Domingos: é porque o médium ele sabe defender a pessoa, ele é quase como um pajé, ele faz sessão, encosta os vivos e encosta os mortos.

Patrícia: mas então, o senhor acha que hoje em dia todo mundo é médium?

Domingos: não, não. Tem as pessoas, porque todo mundo não é todo mundo.

Patrícia: o senhor acha que o governador consulta um médium, é isso?

Domingos: pois é, você acha que vai ser um governador, entrar numa campanha grande, numa luta, só porque ele é o bonitão? Ele vai é muito. Hunhum!

Somanlu, ano 11, n. 1, jan./jun. 2011115 
Patrícia: ele consulta um pajé?

Domingos: ele vai sim senhor! Ele vai primeiro conversar com uma pessoa que seja entendido para defender ele, para ele entrar na luta, que ele não vai entrar sozinho. Ele vai é muito! Por causa de quê que José ${ }^{16}$ [ex-prefeito], hoje tá se acabando, já pintou e bordou e nunca foi preso, nunca foi nada!

Patrícia: mas agora ele saiu?

Domingos: ah, agora ele saiu, mas pagar o que é devido, ele não paga! Será que ele paga? Senão ele teria vendido a fazenda dele todinha, mais ele vender para pagar, eu duvido! Ele tá só? Não tá. Não tá minha branca. Não tá. Ele tem alguma coisa com ele, trabalhando pra ele. Ganhando o dele e defendendo ele do mal. É minha senhora, isso eu the digo e aprovo. A senhora acha que ele sem dinheiro, sem pajé para defesa dele, aqui no centro tem onça.

Patrícia: tem onça?

Domingos: tem, aqui em Guimarães tem onça. Essas pessoas não caçam uma pessoa para defender ele? For mandado pra aí em Brasília, for no Rio de Janeiro, só porque é presidente, é isso, é aquilo e é aquilo outro. Ele vai é muito! Hunhum!

(RIBEIRO, Entrevista, 22.7.2004).

(grifos nossos)

A interpretação algo invertida a respeito das hierarquias que dividem a vida social nos deixa entrever que, para aqueles cujo status social não prescinde de critérios religiosos, as relações entre os homens são percebidas como invariavelmente mediadas por seres do plano transcendental, cujas ações são invisíveis aos olhos daqueles desprovidos dos mencionados dons.

A invisibilidade é entendida como atributo de poder que garante proteção e defesa em tudo distinto do poder econômico ou político, stricto senso. Heróis do passado são descritos como portando este atributo a exemplo de Raimundo Torres que escapou a todas as tentativas de aprisionamento aos quilombolas, empreendidas pelas tropas de linha do período colonial. No Império, segundo os relatos, a perseguição designada pegação tinha como objetivo aprisionar aqueles libertos para prestação de serviços guerreiros. Cotejando estes relatos a documentos conservados pelo Arquivo Público de São Luís é possível que as ações designadas como pegação objetivassem a

116 Somanlu, ano 11, n. 1, jan./jun. 2011 
formação de quadros para exército brasileiro durante a Guerra do Paraguai. Em situações como esta a invisibilidade soma-se a estratégias de fuga ou escondimento a exemplo daqueles que se punham por baixo das saias das mães aos sinais da chegada das tropas ou que buscavam refúgio nas matas, aí permanecendo por longos períodos. Raimundo Torres além de ser muito ágil na luta era capaz de ficar invisível, voar ou tomar a formar de animais sempre que perseguido pelas tropas de linha.

A invisibilidade é considerada como atributo que se herda dos designados antigos como nos relatou a senhora Maria do Socorro Macedo. Entrevistamos essa senhora em 2002 na cidade de Alcântara, onde então residia. Natural do povoado de Arenhengaua localizado ao sul do município dona Maria Batiçá, como é conhecida, relata ter o poder de ficar invisível em situações nas quais não quer ser encontrada. A invisibilidade é atributo dos designados mondogueiros ou bruxeiro da localidade onde nascera, que é e foi no passado quilombo, como ela coloca no trecho da entrevista abaixo.

Maria: Arenhengaua é quilombo, foi quilombo. Quem conta é a minha mãe. Ela conta que essa terra foi dos nossos avós que eram escravos na época. Que a nossa família uma parte de escravo. Eu tinha um tio chamado Raimundo. E o apelido desse meu tio chamava Raimundo "tu-qué-relho". E o que significava? Por que os reis na época tinham o costume de mandar bater nos escravos. E ele sabia retornar, revoltar a pancada. Ele provocava para apanhar. Porque quem batia nele recebia a dor. Aí ficava provocando: rei, ei nosso senhor! Tu qué relho! Que era para ele mandar o feitor bater nele. Ele vinha batia, e ele ficava parado. Então o apelido dele era Raimundo tu-qué-relho, por que ele sabia devolver a pancada. São umas histórias de uns pessoal bruxeiro. Eles eram muito mondongueiro.

Patrícia: o que é mondongueiro?

Maria: Saber fazer as bruxarias, me revoltar em qualquer coisa, virar um peixe,tralhoto, um qualquer coisa, se esconder. Até isso eu herdei um pouco tá! Por que se quiser me esconder de ti ou de qualquer um aí, eu boto essa colher aqui na frente da minha vista e du passa ceguinha aqui e não me olha. E eu te olho e ouço tudo que tu fala, taí uma mágica.

(MARIA BATIÇÁ, Entrevista, 2002).

Somanlu, ano 11, n. 1, jan./jun. 2011117 
Aliás, essas situações de invisibilidade foram relatadas ainda pelo pesquisador Dorival dos Santos em relação ao líder Ednaldo Padilha, quilombola ameaçado de morte que tem o dom da invisibilidade, acionado em momentos onde é procurado pela polícia. No livro Histórias de Garabombo, de autoria de Manuel Scorza, sobre o conflito de terra no Peru há referências a situações de invisibilidade do próprio líder do conflito, que dá o título ao livro (SCORZA, 1975).

Os significados que se revestem estas relações entre os homens e/ou entre estes e seres sobrenaturais não dispensam conteúdos políticos, em sentido estrito, posto que os seres sobrenaturais tanto podem estar à defesa de políticos e poderosos que a eles recorrem e reconhecem seu valor (e sua própria posição de dependência e inferioridade), quanto invariavelmente estes seres garantem proteção tanto aos pajés, benzedores ou devotos de santos e entidades como os Orixás quanto às comunidades as quais estes pertencem. Tais seres sobrenaturais figuram ainda como protetores dos recursos naturais como veremos a seguir.

\section{Os Mineiros, Doutores do Mato, pajés e remedistas de Penalva}

A pesquisa no município de Penalva foi possível através da realização de um trabalho para o Projeto Nova Cartografia Social da Amazônia (PNCSA) que se a propunha a realizar um trabalho de autocartografia com grupos sociais que estão referidos a situações de conflito com fazendeiros dessa região. A realização do trabalho cartográfico que registrasse as situações de conflito vividas pelos grupos, que delimitasse o território reivindicado e refletisse seu modo de viver, tanto quanto tornassem visíveis os símbolos dos ancestrais aí presentes foi possível através da solicitação de uma liderança do MIQCB ao PNCSA

Os conflitos com os fazendeiros parecem ter se intensificado com a reivindicação por parte daqueles que residem na região há muitas gerações como Reserva Extrativista (Resex). Desde então pequenos proprietários têm adquirido porções de terra na área Reivindicada. A solicitação do trabalho de

118 Somanlu, ano 11, n. 1, jan./jun. 2011 
cartografia deu-se assim nesse contexto de luta e partiu de uma liderança antiga do MIQCB e presidente da Associação dos Moradores de Bairro Novo que é originária dessa região. A área reivindicada como Resex asseguraria os direitos territoriais do grupo referido a uma antiga territorialidade designada Enseada da Mata que atualmente é constituída por aproximadamente dez comunidades.

Assim, ao darmos início à pesquisa devíamos compreender inicialmente qual território os agentes concebem como pertencente ao grupo e qual a história de deslocamentos os teria levado a ocupar uma área urbana, conforme supomos, já que estavam localizados em uma área próxima a cidade de Penalva.

Nesse trabalho de campo pudemos observar que as famílias se deslocaram dos povoados localizados na parte central e interna da área reivindicada como (Resex), para a parte periférica, próxima da cidade central do município - Penalva. Tal deslocamento nos fez supor que se tratava de uma área periférica da cidade de Penalva. Durante o trabalho de campo entendemos que o chamado Bairro Novo pertencia a Ensaeda da Mata, área reivindicada como Resex. Ou seja, os entrevistados concebem o Bairro Novo não como um bairro de periferia, mas como uma cabeceira da Enseada da Mata. Em verdade, ao consultarmos o Plano Diretor de Penalva verificamos que o chamado Bairro Novo está situado fora do perímetro urbano. Inserimos a seguir o depoimento no qual a noção de cabeceira é apresentada:

O Bairro Novo não está na sede de Penalva, é muito triste, alguém falou que nem sabia que estava acontecendo dessa forma è̀s vezes a gente se acha tão preocupado da gente estar aqui e dizer que esse bairro não está no mapa, mais se pensar bem é uma forma de alegrar a gente, de fazer outro mapa, mós não saímos da Enseada da Mata, nós não saímos não, nós corremos todos para uma cabeceira na área da Enseada da Mata e ficamos, fizemos um povoado e ficamos oprimidos aqui, para nós ir buscar o que nós precisa está aqui tão longe, né, ficou para os fazendeiros, eles tem todo o conforto, nós corremos prá cá e ficamos sentindo falta de muita coisa lá, nosso serviço lá ficou longe, sentimos falta mesmo da nossa água boa mesmo, lá tá todo o conforto, nós criávamos nossos animais, nossas galinhas, nossos porcos, ficamos sem poder criar (depoimento de Felipe Barbosa dos Santos. PNCSA: 2007).

Somanlu, ano 11, n. 1, jan./jun. 2011119 
Posteriormente, quando retornamos ao campo no período do doutorado, observamos que a separação entre o plano religioso e o plano político se constituía em um limite tênue. As lideranças políticas dos movimentos compartilhavam de um universo simbólico similar às lideranças religiosas que também possuíam um poder local. Tal observação ocorreu em um contexto específico, narrado a seguir, entretanto, deve-se considerar que o status de um indivíduo pode ser construído a partir do exercício de diferentes papéis de forma que não é incomum que em situações de conflito aqueles que passam a representar as expectativas de direito do grupo seja uma autoridade religiosa no plano das relações intra e inter-comunitárias.

A nossa principal informante, no período presidente da Associação do Bairro Novo, dona Nice Machado Ayres, nos levou para conhecer vários denominados terreiros de mina nesse bairro, liderados por autoridades religiosas praticantes do tambor de mina. Os terreiros do Bairro Novo são salões amplos onde se localizam os instrumentos musicais utilizados nos rituais e próprios para a realização dos rituais. No terreiro ou barracão que nos detemos mais tempo, há uma sala menor, onde localizam-se os santos e onde, segundo nossa informante, realizam os chamados trabalhos de espiritismo.

No salão, assim como na sala menor, há imagens de santos. No terreiro ou barracão há um altar com as imagens de duas iemanjás, uma maior e outra menor; e outras imagens como a de Santa Bárbara, Santo Antonio e Santa Luzia. Percebi ainda três tambores, que soube pelas explicações terem nomes específicos: tambor do mato, tambor guia e tambor traseiro, todos tocados na festa de Santa Bárbara pelos chamados batazeiros. No cômodo menor, onde realiza sessões espíritas que podem objetivar retirar doenças ficam as seguintes imagens: Nossa senhora de Fátima, Santo Antonio, Nossa senhora da Piedade e a imagem de ubaloae, responsável pela cura.

Em uma das ocasiões estabeleceu-se um diálogo entre uma autodenomianda mineira, ou seja, iniciada no tambor de mina, conhecida como dona Maria Regina e dona Nice, no período vereadora e coordenadora do MIQCB. Em determinado momento a mineira explicou as diferenças e semelhanças entre o seu trabalho e o da liderança política, disse - ela luta e

120 Somanlu, ano 11, n. 1, jan./jun. 2011 
trabalha no plano material, com gente que existe aqui, eu luto no plano espiritual e nós estamos unidas, eu concordo com a luta dela e ela entende a minha e nos meus trabalhos considero essa luta toda pela terra.

Dona Regina explicou que recebeu um aviso que possuía o que denomina dom - ato de olhar os chamados invisis quando criança, situação vivenciada com freqüência nessa localidade. Os invisis são classificados como chefes ou patrões no plano espiritual, invocado todas as vezes que a mineira vai abrir um tambor de mina. Aquele que tem o dom pode realizar vários denominados trabalhos, em diferentes períodos do ano, sempre que procurados por aquele que recebeu o que denominam feitico ou murrada de uma outra pessoa.

Dona Maria Regina foi iniciada na mina com 14 anos de idade em um terreiro na cidade de São Luis e quando retornou à Penalva fundou seu próprio terreiro, passou a dançar mina e organizar a festa de Santa Bárbara, entre os dias 4 e 6 de dezembro.

No depoimento dona Regina explicou que os encantados precisam das enseadas, dos igarapés e dos mangues pois ali fazem as suas moradas e que se as áreas são destruídas, compradas por fazendeiros para plantio de capim, os encantados somem. Antes de sumirem eles se revoltam com essa situação e podem punir os destruidores.

O nosso informante recebeu o dom aos oito anos de idade quando apresentou problemas sérios de doenças e medos repentinos e posteriormente a ver os chamados invisis. Sua mãe explicou que ele não seria nem o primeiro e nem o último a ver os invisis e o levou para uma iniciação com um tio padrinho. Em entrevista concedida explica que o dom traz limites a vida, aprisiona, pois o individuo passa a ser condicionado por uma entidade que possui uma existência fora do seu corpo, nas suas palavras: se não fosse eles en vivia livre.

Já o senhor Fabrício que reside no povoado lago Mirim, também em Penalva, se autodefine como quilombola, mineiro, pajé e doutor do mato ou remedista. No seu povoado exerce forte liderança na associação de moradores e detém conhecimentos sobre a territorialidade do grupo. Sabe exatamente onde se 
encontram as ruínas dos engenhos, os antigos cemitérios, o local das primeiras casas historia dos primeiros moradores e onde os encantados moram. Ele nos conduziu nas roças, nos mostrou os restos de ruínas e nos apresentou os parentes de seu primo, seu José Maia, um grande curador, falecido e que mobilizava pessoas de várias localidades em busca de cura de doenças.

Seu Fabrício explicou que como doutor do mato já curou tipos variados de doença e que receita também remédios de farmácia, quando o mal extrapola o plano espiritual. Ele explicou que trabalha principalmente com o que denomina doenças de cabeça, principalmente casos de loucura e derrame. Distingue entre os remédios do mato - que curam doenças que são colocadas no corpo, fruto dos feitiços e os remédios de farmácia - que curam as chamadas doenças não colocadas. Explicou ainda que em algumas situações mesmo em casos de feitiço utiliza remédios de farmácia e que inclusive, está com dificuldade com os donos de farmácia que ultimamente estão se recusando a vender os remédios receitados em função da inexistência da chamada receita.

Mesmo que os rituais de mina sirvam para retirar os feitiços o entrevistado estabelece diferenciações entre a mina - onde há a utilização nos rituais de tambores, agogôs e cabaças - e a cura, onde o único instrumento é o maracá. Seu Fabrício executa as duas práticas, daí se autodefinir em algumas situações como mineiro e em outras como pajé.

Explicou que já recebeu muitos presentes e que para um doutor do mato o que merece gratidão é o reconhecimento dos pacientes. $E$ ainda, que o doutor do mato nunca oferece seus serviços, ao contrário, precisa ser procurado pelos designados doentes. Disse que não é para todo mundo que ele realiza os seus trabalhos, nas suas palavras: en faço trabalho de cura para o men povo, se chegar uma pessoa que sei que quer prejudicar nós, não faço, vamos supor, um fazendeiro desses aí, eu não curo ele não. Nesse depoimento, a dimensão política e identitária é reforçada, ou seja, o fato de se recusar a curar um fazendeiro está relacionado ao reconhecimento de um antagonismo, reproduzido e reafirmado nas práticas religiosas do informante.

Apesar dos limites e das restrições que as obrigações religiosas impõe a seus lideres são vivenciadas em certas circunstâncias como um poder,

122 Somanlu, ano 11, n. 1, jan./jun. 2011 
principalmente por aqueles que não possuem o chamado dom, que aceitam como lideres o que trazem consigo essa proeza. Seu Fabricio explica que quem tem o dom sofre e quem não tem acha que é fácil. Ao mesmo tempo explica que a mina encanta e dar poder a quem tem.

Após o trabalho de campo para realização do fascículo as relações com seu Fabrício se estreitaram levando-o a participar do encontro do Projeto Nova Cartografia Social da Amazônia na cidade de São Luis. Nesse encontro discutiu-se as violações aos direitos étnicos e o informante denunciou situações de colocação de cercas elétricas devastações ambientais, ressaltando sempre o direito das famílias do seu povoado à terra e ao reconhecimento dos saberes. Em determinado momento chegou a dizer que mesmo sendo quilombola poderia interferir mais nas lutas em defesa do território, na condição de pajé.

A apresentação preliminar da religiosidade dos dois informantes nos permite dizer que a dimensão religiosa está indissociável da dimensão política, ambas fazem parte do universo social do grupo e estão entrelaçadas.

\section{Considerções finais}

Conforme procuramos mostrar as práticas e saberes referidos aos designados pajés, pajoas, benzendores, benzedeiras, curadores, doutores do mato, consertadores de ossos nos permitiram entrever um sistema de relações de reciprocidade positiva que indica a vigência de diferentes tipos de vínculos estabelecidos entre homens e seres sobrenaturais; ou entre os homens e a natureza; e ainda relações antrópicas propriamente a semelhança do que observou Eduardo Galvão ao realizar uma etnografia na década de 1950 de uma comunidade no Pará, ficticiamente designada Itá.

Este sistema de relações nos permite precisar os diferentes tipos de relações sociais suscetíveis de serem atualizados por uma vasta gama de comunidades que lutam pelos direitos assegurados por lei às comunidades autodefinidas como quilombos.

Não se trata, contudo, de interpretar o processo de auto-identificação destas comunidades como quilombos a partir de critérios primordiais, como 
se a existência de vínculos pré-existentes _ relacionados à tribo, religião, região, casta ou ao parentesco _ fossem constitutivos da afirmação da identidade quilombola.

No presente artigo buscamos argumentar que os processos de afirmação das identidades étnicas, empiricamente abordados, não dispensam critérios político-organizativos. Estes processos autorizam a construção de expectativas de direito que não se eximem em revestir as lutas políticas de conteúdos religiosos, indissociáveis como vimos dos critérios identitários e dos sentimentos de pertencimento étnico dos grupos ou dos sentimentos de participação de uma mesma história de conflitos.

Considerando que o status de um indivíduo pode ser construído a partir do exercício de diferentes papéis, buscamos ressaltar situações que tornam evidente que não é incomum que em situações de conflito aqueles que passam a representar as expectativas de direito do grupo seja uma autoridade religiosa no plano das relações intra e inter-comunitárias.

\section{Notas}

1 “Trabalho apresentado na 28, Reunião Brasileira de Antropologia, realizada entre os dias 02 e 05 de julho de 2012, em São Paulo, SP, Brasil”.

${ }^{2}$ As autoras têm realizado pesquisas nessa região há cerca de uma década. Pesquisas referidas a trabalhos acadêmicos com o propósito de realização de trabalho de campo direcionado à titulação como doutora ou trabalhos profissionais pertinentes a trabalhos voluntários de assessorias a movimentos sociais ou ainda através da atuação em projetos; como exemplo da participação de Cynthia Martins para elaboração do fascículo quebraderias e quilombolas de Enseada da Mata (Penalva) e Alcântara e de Patrícia Portela na elaboração do fascículo de Alcântara para o Projeto Nova Cartografia Social da Amazônia (PNCSA).

${ }^{3}$ A recente lei n. ${ }^{\circ}$ 1370/11 aprovada em São João do Triunfo é um exemplo de como as lutas pelo reconhecimento dos saberes tradicionais tem se inserido nos pleitos reivindicatórios. Tal lei dispõe sobre o reconhecimento dos ofícios tradicionais de cura em suas distintas modalidades.

${ }^{4}$ O decreto estadual n. 7320 de setembro de 1980 desapropriou 52000 hectares do município de Alcântara para implantação do dito C.L.A. Ao passar para a instância de decisão federal são acrescidos mais 10000 hectares: o decreto presidencial datado de 8 de agosto de $1991 \mathrm{em}$ seu Art., $1^{\circ}$ declara de utilidade pública, para fins de desapropriação pela União, 62000 hectares deste município; o que corresponde a mais da metade da área deste e atinge a mais de 2000 famílias de trabalhadores rurais.

124 Somanlu, ano 11, n. 1, jan./jun. 2011 
${ }^{5}$ Conforme dispõe a Portaria n ${ }^{\circ} 35$ registrada no Livro de Cadastro-Geral n. ${ }^{\circ} 001$ da Fundação Cultural Palmares, sob o n ${ }^{\circ}$, em 01 de março de 2004 e publicada no Diário Oficial da União n ${ }^{\circ}$ 43 de 4 de março de 2004, Seção 1, f 07. De acordo com o registro n.96, f.100 desta Portaria 65 comunidades deste município são beneficiadas pelo art. $1^{\circ}$ da Lei n. ${ }^{\circ} 7668$ de 22 de agosto de 1988 , art. $2^{\circ}, \iint 1^{\circ}$ e $2^{\circ}$, art. $3^{\circ}, \int 4^{\circ}$ do decreto 4887 de 20 de novembro de 2003.

${ }^{6}$ Para um aprofundamento dos processos de ruptura e de conquistas que demarcam as novas relações entre o Estado Brasileiro e os designados "povos indígenas e tribais" consultar: Almeida, Alfredo Wagner Berno de. Nas Bordas da política étnica: os quilombos e as políticas sociais. In: Quilombos e as Novas Etnias. Manaus: UEA Edições, 2011..

${ }^{7}$ Os encantados são seres que habitam pedras, mares e outras localidades. Os encantados não são seres que morreram e voltaram, ao contrario, possuem uma existência própria e sempre estarão presentes na terra (FERRET'TI: 2000).

${ }^{8}$ Por grupo étnico, Weber entende: “Chamaremos grupos étnicos aqueles grupos bumanos que, em virtude de semelhanças no habitus externo ou nos costumes, ou em ambos, ou em virtude de semelhanças de colonização e imigração, nutrem uma crença subjetiva na procedência comum, de tal modo que esta se torna importante para a propagação de relações comunitárias, sendo indiferente se existe ou não uma comunidade de sangue efetiva. $A$ 'comunhão étnica' distingue-se da 'comunidade de clã'pelo fato de aquela ser apenas um produto de um 'sentimento de comunidade' e não de 'uma comunidade'verdadeira, como o clã, a cuja essência pertence uma efetiva ação comunitária. A comunhão étnica (no sentido que damos) não constitui, em si mesmo, uma comunidade, mas apenas um elemento que facilita relações comunitárias. Fomenta relações comunitárias de natureza mais diversa, mas sobretudo, conforme ensina a experiência, as politicas. Por outro lado, é a comunidade politica que costuma despertar, em primeiro lugar, por toda parte, mesmo quando apresenta estruturas muito artificiais, a crenca na comunhão étnica, sobrevivendo esta geralmente à decadência daquela, a não ser que diferenças drásticas de costume de bábito, particularmente de idioma o impeçam” (WEBER, 2000, p. 270, v 1).

${ }^{9}$ Barth entende que com isso pode-se resolver os problemas conceituais das abordagens precedentes: o observador externo e seu inventário de traços objetivos sai de cena dando lugar apenas para o que é socialmente relevante para os próprios atores; e a continuidade do grupo étnico deixa de ser atribuída à sua permanência no tempo para depender da manutenção da fronteira uma vez que a unidade étnica corresponde a um grupo atributivo. Sobre o problema da contrastividade cultural e a crítica ao observador externo em Barth consultar: O'DWYER, Eliane Cantarino. Resenha: BARTH, Fredrik. O Guru, o Iniciador e Outras Variações Antropológicas. Mana vol.7, n. ${ }^{\circ}$ 1. Rio de Janeiro Apr. 2001.

${ }^{10}$ A esse respeito consultar: FOUCAULT, M. "Sobre a arqueologia das ciências: reposta ao círculo epistemológico". In: FOUCAULT, M. et al. Estruturalismo e Teoria da linguagem. Petrópolis: Vozes, 1968, p. 9-55. FOUCAULT, M. 1995. A arqueologia do saber. Rio de Janeiro: Florense Universitária. 239p.

${ }^{11}$ As formulações ora apresentadas foram extraídas da tese de doutorado de Patrícia Portela apresentada ao Programa Pós-Graduação de Antropologia da UFF em maio de $2011 \mathrm{com}$ o título Canelatiua, Terra dos Pobres, Terra da Pobreza: uma territorialidade ameaçada, entre a recusa de virar Terra da Base e a titulação como Terra de Quilombo.

Somanlu, ano 11, n. 1, jan./jun. $2011 \quad 125$ 
${ }^{12} \mathrm{O}$ uso das aspas aqui se deve à generalidade a que o termo "remédios" se aplica. O termo é utilizado tanto para se referir aos males físicos, quanto aos espirituais, separados ou conjuntamente, isto é, se utiliza em referência a enfermidades físicas, males espirituais ou para enfermidades que associam problemas espirituais a doenças físicas. Além disso, os chamados remédios assumem uma variedade de formas, isto é, referem-se a uma grande variedade de chás, de pomadas e de banhos cuja indicação adequada somente pode ser atribuída pelos especialistas no assunto.

${ }^{13}$ Tirar sangue porpalavras remete a um tipo de saber habilitado a estancar hemorragias através da combinação da aplicação de determinadas ervas a palavras mágicas; cubreiro e fogo selvagem dizem respeito a problemas de pele seja no corpo, seja no couro cabeludo respectivamente. Para certos enfermos, no entanto, estes problemas de caráter físico podem estar associados a problemas de foro espiritual a exemplo da moléstia conhecida por bucho de criança ou barriga virada que pode apresentar-se associada a mau-olhado.

${ }^{14}$ Não se trata assim de uma transmissão por descendência unilinear como a observada por Evans-Pritchard (2005) entre os azande. Em referência à situação enfocada, a herança deste dom pode ser transmitida pelos pais aos filhos independentemente do sexo, ou seja, nada impede que uma filha possa herdar este dom de seu pai ou um filho de sua mãe.

${ }^{15}$ Em algumas situações, aqueles que recorrem em vão ao uso de "remédios" com o objetivo de inibir a transmissão hereditária podem viver este dom como espécie estorvo que lhe atormenta durante toda a sua vida. Em certas épocas, o dom se manifesta de forma mais patente, em outras ele é percebido como inativo. De outra parte, é a possibilidade dele permanecer inativo durante certo período da vida que permite que uma pessoa só venha a manifestá-lo e reconhecê-lo em sua fase adulta, mesmo que ele seja adquirido por nascimento.

${ }^{16}$ Para preservar o entrevistado mudamos o nome do político citado.

\section{Referências}

ALMEIDA, Alfredo Wagner B. Nas Bordas da política étnica: os quilombos e as políticas sociais. In: Quilombos e as Novas Etnias. Manaus: UEA Edições, 2011.

. Terras de quilombo, terras indígenas, "babaçuais livres", "castanhais do povo", faxinais e fundos de pasto: terras tradicionalmente ocupadas. Manaus: PPGSCA-UFAM, 2006.

Os quilombolas e a base de foguetes de Alcântara, vol I. Brasília: MMA, 2006, p. 1-69.

ALMEIDA, Alfredo Wagner Berno de, SHIRAISHI NETO, Joaquim e MARTINS, Cynthia Carvalho. Guerra Ecológica nos Babaçuais. O processo de

126 Somanlu, ano 11, n. 1, jan./jun. 2011 
devastação dos palmeirais, a elevação do preço de commodities e o aquecimento do mercado de terras na Amazônia. São Luís, Lithograf, 2005.

AQUINO, Txai Terri. Papo de indio. Manaus: UEA Edições, 2012. 351.

BARTH, Fredrik. Os grupos étnicos e suas fronteiras. In: O guru, o iniciador e outras variaçoes. Rio de Janeiro: Contra Capa, 2000, p. 25-67.

Cosmologies em the making. A generative approach to cultural variation in inner New Guinea, Cambridge University Press, 1995.

DURKHEIM, Émile. Introdução: Objeto da pesquisa - sociologia religiosa e teoria do conhecimento, In: As formas elementares da vida religiosa: o sistema totêmico na Austrália. São Paulo: Martins Fontes, 2003.

ERIKSEN, Thomas Hylland. The cultural contexts of ethnic differences. Man, Londres, v. 26, n. 1, 1991.

EVANS-PRITCHARD, E. E. Ruxarias, Oráculos e Magia entre os Azande. Rio de Janeiro, Jorge Zahar Ed., 2005.

FERRETTI, Mundicarmo. Desceu na Guma. O Caboclo no Tambor de Mina em um terreiro de São Luís - A Casa Fanti-Ashanti. 2. ed. São Luís: EDUFMA, 2000.

FRAZER, James G. The Golden Bough. New York, Macmillan, 1979 [18901922]. Abridged Edition.

FRAZER, Nancy. Da redistribuição ao reconhecimento? Dilemas da justiça na era pós-socialista. In: SOUZA, J. (org). Democracia Hoje. Brasília, Ed. UNB, 2001.FOUCAULT, M. 1995. A arqueologia do saber. Rio de Janeiro: Florense Universitária. 239p.

GALVÃO, Eduardo. Santos e Visagens. São Paulo: Companhia Editora Nacional, 1954.

GINZBURG. 1999. Feitiçaria e piedade popular. In: Mitos emblemas e sinais. São Paulo: Companhia das Letras. pp. 15-39.

GODELIER, Maurice. Community, society, culture: three Keys to understanding today's conflicted identities. Journal of the Royal Anthropological Institute. (N.S) 16, 1-11 2010. 
GULLAR, Ferreira. Poema Sujo. Rio de Janeiro: José Olympio, 2004 [1975].

MARX, K. e ENGELS, F. Manifesto do Partido Comunista. In: MARX, K. e ENGELS, F. Obras escolbidas. São Paulo: Alfa-Ômega, s/d.

MOGAN.Lewis H. Os períodos étnicos. In: A Sociedade Primitiva. Tradução Maria Helena Barreiro Alves. Portugal: Editorial Presença; Brasil: Livraria Martins. Fontes, 2005, v. I. p. 41-66.

NADER, Laura. Harmonia Coerciva: a economia política dos modelos jurídicos.

O'DWYER, Eliane Cantarino. Os quilombos e as fronteiras da antropologia. Antropolítica. Niterói, n. 19, 2005.

Resenha: BARTH, Fredrik. O Guru, o Iniciador e Outras Variações Antropológicas. Mana, v.7 n. 1. Rio de Janeiro Apr. 2001.

PEREIRA JÚNIOR, Davi. Quilombos de Alcântara: Território e Conflito intrusamento do território das comunidades quilombolas de Alcântara pela empresa binacional, Alcântara Cyclone Space. Manaus: Editora da Universidade Federal do Amazonas, 2009.

PORTElA, Patrícia. Canelatiua, Terra dos Pobres, Terra da Pobreza: uma territorialidade ameaçada, entre a recusa de virar Terra da Base e a titulação como Terra de Quilombo. Tese de Doutorado. Programa Pós-Graduação em Antropologia PPGA/UFF, 2011.

Relatório antropológico de identificação: Remanescentes de Quilombo do Arapemã Residentes no Maicá. Seminário Projeto Identificação Territorial de Comunidades Quilombolas de Santarém - Oeste do Pará. Santarém, dezembro de 2010. Mimeo.

SANTOS, Dorival dos. Quem come manga não pode tomar leite: narrativas sobre a territorialidade em Tramaúba - Cajari (MA) IN Insurreição de saberes: práticas de pesquisa em comunidades tradicionais. PNCSA, São Luís, 2011.

SCORZA, Manuel. Histórias de Garabombo. Ed. Civilização, 1975.

128 Somanlu, ano 11, n. 1, jan./jun. 2011 
TURNER, Victor. A medicina Lunda e o tratamento das doenças. In: Floresta de Símbolos: aspectos do ritual Ndembu. Niterói: Eduff, 2005, p. 379-447.

WEBER, Max. Relações comunitárias étnicas. In: Economia e sociedade: fundamentos da sociologia compreensiva. Vol 1. Brasília: UnB, 2000, p. $267-$ 277.

Os Tipos de Dominação. In: Economia e sociedade: fundamentos da sociologia compreensiva. Vol 2. Brasília: UnB, 2000, p. 139-161.

\section{Documento consultado}

Lei n. 1370/11. Dispõe sobre o reconhecimento dos ofícios tradicionais de cura em suas distintas modalidades; benzedores (as), curadores (as) de rendiduta ou machucadura, massagistas tradicionais, parteiras e regulamenta o livre acesso a coleta de ervas e plantas nativas, no município de São João do Triunfo, no Estado do Paraná e dá outras providências. 